\title{
Ways to Increase the Competitiveness of Tourism Services Through the Application of Digital Technologies in Uzbekistan
}

\author{
Tuxliev Iskandar Suyunovich \\ Professor of "Tourism", Doctor of Economics, Samarkand Institute of Economics and Service, \\ Uzbekistan \\ Sobirov Bobur \\ Samarkand Institute of Economics and Service
}

\begin{abstract}
The article describes how today, due to the rapid development of the digital economy and the development of advanced technologies in the near future, they represent a new type of economic relations in all sectors of the global market, which can become the main form of exchange of money around the world.
\end{abstract}

Keywords: digital technologies, tourism, economy, innovations.

\section{INTRODUCTION}

For a very long time, the digital economy determines the development vector of socio-economic systems of micro, meso, macro levels. This, in turn, increases the need for comprehensive digital transformation processes analysis and research.

Various factors of competitiveness of the tourism industry in the context of the digital economy have been extensively analyzed in the scientific literature. These include market conditions, level of socio-economic development, environmental policy, human resource base, infrastructure quality, level of innovative development, and more. Their level of development has a great impact on the competitiveness of the tourist area. Competitive regions offer a wide range of tourism products; attract potential tourists based on their image (e.g. natural landscapes, clean, clean lakes, advanced environmental policies, all of which are an ideal basis for eco-tourism and enhance the country's reputation for environmental cleanliness. At the same time, the services provided are relatively high.

Globally, the transition from a traditional economy to a digital economy associated with the industrial revolution is taking place at a rapid pace. New directions in the socio-economic development of modern countries, first of all, innovative economy based on the idea of $\mathrm{J}$. Schumpeter, development trends of postindustrial society based on the American scientist D. Bell, J. Hawkins' theory of knowledge economy or creative economy, J. Bankler's scientific work "Digital Economy" the sectoral economy put forward in the concepts presented and the digital economy introduced by D. Tepskott.

\section{MAIN PART}

In the development of today's innovative activities of Uzbekistan, consistent measures are also being taken to develop the digital economy, e-commerce systems for Electronic Document Exchange in state bodies and other organizations, as well as providing services to individuals and legal entities are being introduced gradually. In order to ensure the rapid digital development of economic sectors, 
social sphere and the system of public administration, including the further improvement of the provision of electronic public services, the decree of the president of the Republic of Uzbekistan "on approval of the strategy of" digital Uzbekistan-2030"and measures for its effective implementation was adopted on October 5, 2020. The strategy determines the strategic goals, priorities and long-term objectives of the development of the digital economy and e-Government of the Republic of Uzbekistan, as well as the goals of sustainable development of the United Nations Organization and serves as the basis for the wider introduction of digital technologies, based on the priorities set in the e-government development rating.

Tourist firms and tourism management organizations, which are entering the international market, are faced with the problems of mastering new information technologies, which in their activity is considered a modern concept of tourist business as well as a necessary condition of international integration. Planning the development of tourism in the regions of the Republic of Uzbekistan is complicated by the lack of information and statistics on the main tourist resources. Accordingly, the current issue in tourism is the analysis of existing information systems, the study of widespread areas of application of information technology and the development of recommendations to improve the competitiveness of tourism services based on the use of information systems.

The tourism sector of Uzbekistan is also one of the sectors that apply a lot of information and communication technologies and are provided with the latest computer technologies. It all depends on the nature of the carriers of information and the fact that the transition of society to the increasingly digitization process also leads to the digitization of information and information carriers. The following main features should be taken into account when digitizing the tourism sector:

- first of all, as a result of the lack of storage of time and information in tourism, the event is tied to employees;

- secondly, the condition for the implementation of the tourist product on time and in a certain space;

- in the end, the tourist product is made up of various sectors that make up a lot of tourism (transport, accommodation, entertainment services), which require coordination and entrepreneurship from the tour operator in the delivery of their services to tourists.

All this can be done by the geo-finance system (GAT), which is formed in tourist organizations. GAT in the form of its digital competence includes information about the following objects:

- global or planetary GAT in the area of regional coverage;

- sub-continental GAT;

- regional GAT in state status;

- subregional GAT;

- local GATS.

As you know, GAT requires data to be in graphic, text, audio, video and other formats. Regardless of what information they should be digitized. It is in this case that the creator and the user are required to have the necessary knowledge in Information Technology. These GAT technologies are used for the purpose of studying and meeting the changing requirements of Tourism. 
Analysis of graphic data of tourism in Uzbekistan it was determined that on the basis of the principle of composing them, tourist objects, components of Real events and all types of services rendered are not in digital form. For this reason, we believe that all information on tourism needs to be processed in Gat.

Due to the lack of a single database of the main tourist resources in the planning of Tourism Development in the regions of the Republic of Uzbekistan, it is necessary to analyze the existing information systems in tourism, study the possibilities of using digital technologies and develop relevant recommendations on the tourism market based on information systems.

Today, it is necessary to formulate a geo-information system that is one of the tested and proven methods of increasing the competitiveness of tourism services abroad through the use of digital technologies in Uzbekistan. Among the main tasks that must be solved in the introduction of the geofinance system into the tourism industry are the following::

- providing tourists with up-to-date and accurate information on a wide range of topics;

- to help small scale tourist organizations promote their product cheaply and effectively;

- ability to ensure the dissemination of information of any cheap tourist firm through mobile geo-commerce systems;

- establishment of various links between any participants of the tourist market;

- offering an alternative marketing system and information distribution channels;

- to create an open economic geo-finance system for the sale of tourist services electronically;

- collection and processing of multimedia marketing materials using the mobile Geoinformation system;

- implementation of standard Geo-information systems tools and technologies;

- normative-information and creation of a spatial data base with a natural-climatic, recreational, cultural-historical description, connection to a remote normative - database.

Together with the Ministry of Tourism and sports and local authorities, we propose to develop programs for the development of regional tourism on the basis of the use of the Geoinformation system in the implementation of the tasks set out in the"road map"of the implementation of the strategy" digital Uzbekistan-2030". The following measures should be taken into account in these regional programs:

- natural monuments and tourism destinations in the regions-certification of services provided and maintaining the cadastre of tourist places-digitization of information on cash;

- design new tourist routes and digitize maps using the tourist Geoinformation system;

- digitization of the system of continuous monitoring of tourism security in the region using modern information technologies;

- fully implement the E-guest system in all hotels in the country and integrate the system into the regional geoportalga;

- formation of a database on tourist addresses, cafes, restaurants, hotels, shopping centers, drop-in offices, hospitals, pharmacies, markets, taxis, bank branches and their location for the application of technology of digitization in tourism;

- to increase the scale of digitization of the order of identification of GIDS operating in the regions; -increase the share of electronic database of photo and video materials used to promote the tourist 
potential of the regions.

\section{CONCLUSION}

In this regard, in order to increase the competitiveness of tourist and recreational services in Uzbekistan, it is necessary to introduce a new direction of education in higher education institutions in the field of formation and development of geographic information systems using digital technologies and conduct research on this topic.

\section{REFERENCES:}

1. Amadeus Traveler Trend Observatory: Future Traveler Tribes 2030: Understanding tomorrow's Travel (2015). http://www.amadeus.com/documents/future-traveller-tribes2030/travel-report-future-traveller-tribes-2030.pdf

2. Años, E., Sousa, F., Ramos, K .: New technologies and tourism: on the VaiBrasil website. Caderno Virtual de Turismo 6 (4) (2006)

3. Atsori, L., Iera, A., Morabito, G .: Internet of Things: an overview. Comput. Netw. 54 (15), 2787-2805 (2010).

4. Avelard, E. et al .: Arquitetura de Comunicação para Cidades Inteligentes: Uma propostaheterogénea, extensível e de baixo custo. Federal University of Pernambuco (UFPE), Recife (2010)

5. Shumpeter Y.A. Theory of economic development. Capitalism, socialism and democracy. M $\therefore$ Eksmo, 2007. p. 862.

6. Bell D. Gryadushchee postindustrialnoe obshchestvo. Opyt sotsialnogo prognozirovaniya. M.: Academia, 1999. p. 956.

7. Howkins J. The Creative Economy: How People Make Money from Ideas. London: Penguin. 2001.

8. SOBIROV, B., \& ALIMOVA, M. (2019). Accelerated development of tourism in Uzbekistan: trends, reforms and results. E-methodology, 6(6), 128-140.

9. Tukhliyev, I., \& Safarov, B. (2012). Tourism Basics. T.:" New edition, 34.

10. Асланова, Д. Х., Саттарова, 3. И., \& Алимова, М. Т. (2016). Региональный туристский кластер как инструмент повышения эффективности экономики региона. Научный результат. Экономические исследования, 2 (1 (7)).

11. Toirxonovna, A. M., Obloqulovich, U. T., \& Tuychiev, I. I. (2020). Institutional Framework for the Development of the Tourism Market. Indonesian Journal of Law and Economics Review, 8, 10-21070.

12.

13. Алимова, М. Т., \& Рахмонов, Ш. Ш. (2018). Инновационный механизм развития туризма в регионах Узбекистана. Вопросы науки и образования, (1 (13)).

14. Рахмонов, Ш. Ш., \& Алимова, М. Т. (2018). Туризм-мощный катализатор социальноэкономического развития региона. International Journal of Innovative Technologies in Economy, (3 (15)).

15. Toirxonovna, A. M. (2016). LM, Analysis of trends and forecasting the development of the international tourism market. SAARJ Journal on Banking \& Insurance Research, 5(1), 50-70. 
16. Tuxliyev, I. S., Hayitboyev, R., Ibodullaev, N. E., \& Amriddinova, R. S. (2010). The basics of tourism: A handbook. Samarkand: SamISI.

17. Alimova, M. T., Nasimov, A. R., \& Rakhmonov, S. S. (2020). THE METHODOLOGY OF THE FORMATION OF TOURIST CLUSTERS: THE EXAMPLE OF THE REGIONS OF UZBEKISTAN. PalArch's Journal of Archaeology of Egypt/Egyptology, 17(7), 1446214475.

18. Alimova, M. T., Obloqulovich, U. T., \& Rakhmonov, S. S. (2020). ASYSTEMATIC APPROACH TO THE DEVELOPMEN TO THE REGIONAL TOURISM MARKET. PalArch's Journal of Archaeology of Egypt/Egyptology, 17(7), 14252-14261.

19. Suyunovich, T. I., \& Nuraliyevich, M. A. (2020). General architecture of a geopartal system created for tourism. International Journal on Integrated Education, 3(2), 115-117.

20. Aslanova, D. X., \& Alimova, M. T. (2020). METHODOLOGY FOR THE IDENTIFICATION OF TOURIST CLUSTERS: THE EXAMPLE OF THE REGIONS OF UZBEKISTAN. PalArch's Journal of Archaeology of Egypt/Egyptology, 17(6), 1482014833.

21. Suyunovich, T. I., \& Nuraliyevich, M. A. (2020). General architecture of a geopartal system created for tourism. International Journal on Integrated Education, 3(2), 115-117.

22. Tuxliyev, I. S., Hayitboyev, R., Ibodullaev, N. E., \& Amriddinova, R. S. (2010). The basics of tourism: A handbook. Samarkand: SamISI.

23. Benkler Y. The Wealth of Networks: How Social Production Transforms Markets and Freedom. New Haven, Conn: Yale University Press, 2006. 515 r.

24. Tapscott D. The digital economy: promise and peril in the age of networked intelligence. New York; Montreal: McGraw-Hill, 1996. 342 p. 